Jurnal Abdidas Volume 2 Nomor 3 Tahun 2021 Halaman 670-675

JURNAL ABDIDAS

http://abdidas.org/index.php/abdidas

\title{
Pendampingan Masyarakat dalam Penguatan Imunitas Tubuh dengan Gizi Seimbang dan Suplemen di Era Adaptasi Kebiasaan Baru
}

\author{
Rosmauli Jerimia Fitriani ${ }^{1}$, Margala Juang Bertorio ${ }^{2}$, Rahmat A. Hi Wahid ${ }^{3}$, Suharman $^{4}$ \\ Gizi, Fakultas Sains dan Teknologi, Universitas PGRI Yogyakarta, Indonesia ${ }^{1}$ \\ Farmasi, Fakultas Sains dan Teknologi, Universitas PGRI Yogyakarta, Indonesia ${ }^{2,3}$ \\ Teknologi Hasil Pertanian, Fakultas Pertanian, Universitas PGRI Yogyakarta, Indonesia ${ }^{4}$ \\ E-mail: rosmaulijf@upy.ac.id ${ }^{1}, \underline{\text { margala@upy.ac.id }}$, rahmat@upy.ac.id ${ }^{3}, \underline{\text { suharman@upy.ac.id }^{4}}$
}

\begin{abstract}
Abstrak
Pandemi Covid-19 sudah terjadi lebih dari satu tahun. Pada masa adaptasi kebiasaan baru diharapkan dapat menerapkan adaptasi kebiasaan baru di segala lini masyarakat, tempat pendidikan, kantor, tempat umum dan lainnya. Perlu adanya pendampingan masyarakat untuk meningkatkan protokol kesehatan. Pendampingan masyarakat bertujuan untuk menumbuhkan pengetahuan masyarakat tentang gizi seimbang dan suplemen kesehatan, menumbuhkan pengetahuan masyarakat dalam membedakan suplemen kesehatan dan obat sebagai terapeutik serta menumbuhkan pengetahuan masyarakat tentang PHBS. Pendampingan ini dilaksanakan di Padukuhan Karang Tengah, Desa Nogotirto, Kecamatan Gamping, Kabupaten Sleman, Provinsi Daerah Istimewa Yogyakarta. Kegiatan pengabdian ini menggunakan metode ceramah dan demonstrasi. Metode ceramah untuk menjelaskan tentang tentang gizi seimbang dan suplemen kesehatan, membedakan suplemen kesehatan dan obat sebagai terapeutik dan pengetahuan masyarakat tentang PHBS. Metode demonstrasi untuk mempraktikkan Perilaku Hidup Bersih dan Sehat (PHBS) yaitu 3M (Memakai masker, Mencuci tangan, Menjaga jarak dan Menghindari kerumunan) di era adaptasi kebiasaan baru. Pengabdian ini dilakukan secara tatap muka, kemudian dilanjutkan dengan dibentuknya grup WhatsApp untuk berdiskusi lebih lanjut. Pengabdian ini mendapat respon yang baik oleh masyarakat dan peserta mendapatkan ilmu baru mengenai gizi seimbang dan suplemen di era adaptasi kebiasaan baru.
\end{abstract}

Kata kunci: era adaptasi kebiasaan baru, gizi seimbang, suplemen kesehatan, perilaku hidup bersih dan sehat

\section{Abstract}

The Covid-19 pandemic has been going on for more than a year. During the new normal, new habits are expected to apply new normal in all lines of society, places of education, offices, public places, and others. Community assistance is needed to improve health protocols. Community assistance aims to grow public knowledge about balanced nutrition and health supplements, grow public knowledge in differentiating health supplements and drugs as therapeutics, and grow public knowledge about PHBS. This assistance was carried out in Padukuhan Karang Tengah, Nogotirto Village, Gamping District, Sleman Regency, Yogyakarta Special Region Province. This service activity uses lecture and demonstration methods. The lecture method explains balanced nutrition and health supplements, distinguishing health supplements and drugs as therapeutics and public knowledge about PHBS. Demonstration method for practicing clean and healthy behavior, namely $3 M$ (Wearing masks, Washing hands, Keeping a distance, and Avoiding crowds) in new normal. This service is carried out face-to-face, followed by forming a WhatsApp group for further discussion. This service received a good response from the community, and participants gained new knowledge about balanced nutrition and supplements in the new normal.

Keywords: new normal, balanced nutrition, health supplements, practicing clean and healthy behavior

Copyright (c) 2021 Rosmauli Jerimia Fitriani, Margala Juang Bertorio, Rahmat A. Hi Wahid, Suharman $\square$ Corresponding author

Address : Jl. PGRI I Sonosewu No.117 Yogyakarta 55182

Email : rosmaulijf@upy.ac.id

DOI $\quad:$ https://doi.org/10.31004/abdidas.v2i3.333

ISSN 2721-9224 (Media Cetak)

ISSN 2721- 9216 (Media Online) 
671 Pendampingan Masyarakat dalam Penguatan Imunitas Tubuh dengan Gizi Seimbang dan Suplemen di Era Adaptasi Kebiasaan Baru - Rosmauli Jerimia Fitriani, Margala Juang Bertorio, Rahmat A. Hi Wahid, Suharman

DOI: https://doi.org/10.31004/abdidas.v2i3.333

\section{PENDAHULUAN}

Coronavirus Disease 2019 (Covid-19) adalah penyakit menular yang disebabkan oleh Severe Acute Respiratory Syndrome Coronavirus 2 (SARS-CoV-2). SARS-CoV-2 merupakan coronavirus jenis baru yang belum pernah diidentifikasi sebelumnya pada manusia. Ada setidaknya dua jenis coronavirus yang diketahui menyebabkan penyakit yang dapat menimbulkan gejala berat seperti Middle East Respiratory Syndrome (MERS) dan Severe Acute Respiratory Syndrome (SARS). Tanda dan gejala umum infeksi Covid-19 antara lain gejala gangguan pernapasan akut seperti demam, batuk dan sesak napas. Masa inkubasi rata-rata 5-6 hari dengan masa inkubasi terpanjang 14 hari. Pada kasus Covid-19 yang berat dapat menyebabkan pneumonia, sindrom pernapasan akut, gagal ginjal, dan bahkan kematian (Kemenkes RI, 2020). Covid-19 dapat dicegah dengan konsumsi makanan dengan gizi seimbang yang dapat meningkatkan sistem kekebalan tubuh dan menurunkan risiko penyakit kronis dan penyakit infeksi, serta memberikan perlindungan ekstra bagi tubuh. Dalam isi piring makan sehari-hari, sebaiknya terdiri dari makanan pokok yang merupakan sumber karbohidrat, dapat berupa nasi, jagung, kentang, umbi- umbian. Lauk pauk yang merupakan sumber protein dan mineral; Lauk hewani antara lain: daging, ikan, ayam dan telur; Lauk nabati antara lain: tahu, tempe, dan kacang-kacangan. Sayuran dan buah merupakan sumber vitamin, mineral dan serat. Terutama sayuran dan buah yang berwarna, banyak mengandung vitamin dan berfungsi sebagai antioksidan yaitu vitamin A, C, dan E (Kemenkes, 2020) (Susilo et al., 2020).

Salah satu upaya yang dapat dilakukan oleh setiap orang agar terhindar dari Covid-19 adalah memelihara atau menjaga daya tahan tubuh, antara lain dengan mengonsumsi suplemen kesehatan dan obat herbal. Sistem kekebalan yang baik akan menghasilkan antibodi yang dapat melindungi tubuh dan membunuh virus patogen (Chowdhury, Hossain, Kashem, Shahid, \& Alam, 2020). Selain itu, gaya hidup sehat, mental dan fisik yang baik juga juga hal penting dalam melindungi tubuh dari Covid-19 (Balanzá-Martínez, Atienza-Carbonell, Kapczinski, \& De Boni, 2020)(Park, Kim, Yang, Lim, \& Park, 2021).

Pandemi Covid-19 telah merubah tatanan kehidupan sehari-hari, sehingga adanya Era Adaptasi Kebiasaan Baru (AKB). Era adaptasi kebiasan baru yaitu jika sedang flu, di rumah aja. Sering cuci tangan pakai sabun dengan air mengalir saat akan atau selesai beraktivitas dan sedia hand sanitizer saat berpergian. Tidak lupa memakai masker saat keluar rumah. Selalu dan tetap menjaga jarak antara orang lain yaitu dengan menjaga jarak 1 hingga 2 meter dan menjauhi kerumunan/keramaian termasuk saat di kendaraan umum. Tidak lupa setibanya di rumah langsung mandi dengan air mengalir dan juga menggunakan sabun. Dalam menyapa tidak perlu bersalaman ataupun bersentuhan. Minimalisir menggunakan uang kertas atau logam dan diusahakan bertransaksi menggunakan uang elektronik. Diharapkan bagi balita dan lansia untuk tetap di rumah saja, segala kebutuhan dapat disediakan 
672 Pendampingan Masyarakat dalam Penguatan Imunitas Tubuh dengan Gizi Seimbang dan Suplemen di Era Adaptasi Kebiasaan Baru - Rosmauli Jerimia Fitriani, Margala Juang Bertorio, Rahmat A. Hi Wahid, Suharman

DOI: https://doi.org/10.31004/abdidas.v2i3.333

kecuali kondisi darurat yang mengharuskan keluar rumah (Selviana, 2020)(Jenderal \& Masyarakat, 2020).

Sudah lebih dari satu tahun pandemi Covid19 di Indonesia, masyarakat diharapkan untuk mematuhi protokol kesehatan yang telah ditetapkan oleh pemerintah. Pada masa adaptasi kebiasaan baru yang dicanangkan oleh pemerintah diadopsi dari organisasi kesehatan dunia yaitu WHO, menerapkan adaptasi kebiasaan baru di segala lini masyarakat, tempat pendidikan, kantor, tempat umum dan lainnya. Padukuhan Karang Tengah, Desa Nogotirto, Kecamatan Gamping, Kabupaten Sleman, Provinsi Daerah Istimewa Yogyakarta diharapkan selalu menerapkan protokol kesehatan tersebut.

Salah satu fungsi dan tugas pendidikan tinggi yaitu untuk menjembatani program pemerintah agar dapat dilakukan di masyarakat dan meluruskan isu-isu kesehatan di masyarakat. Masyarakat dan kader Padukuhan Karang Tengah mungkin sudah mendapatkan penyuluhan terkait adaptasi kebiasaan baru oleh pemerintah melalui perangkatnya namun kami ingin lebih rinci untuk menjelaskan arti penting gizi seimbang berdasarkan pedoman dan panduan yang ada untuk masyarakat didampingi oleh ahlinya dalam bidang gizi serta juga penjelasan mendalam mengenai suplemen yang dapat dikonsumsi oleh masyarakat untuk membantu meningkatkan imunitas tubuh sebagai tindakan pencegahan terhadap paparan Covid-19 oleh farmasis dan apoteker, yang kemudian didampingi juga oleh ahlinya dalam bidang teknologi hasil pertanian di mana kita dapat mengolah makanan sehat untuk mendapatkan vitamin dan mineral penunjang kesehatan di masyarakat. Berdasar ini mengharapkan masyarakat akan menjadi lebih memahami informasi pada masa adaptasi kebiasaan baru sekaligus menjadi lebih bertanggung jawab akan kesehatan diri sendiri, keluarga, dan masyarakat disekitarnya.

\section{METODE}

Pengabdian mengenai gizi seimbang dan konsumsi suplemen ini dilakukan di Padukuhan Karang Tengah, Desa Nogotirto, Gamping, Sleman, Daerah Istimewa Yogyakarta pada bulan April 2021 diawali dengan pertemuan tatap muka, yang menerapkan protokol kesehatan.

Metode yang digunakan untuk mendukung realisasi kegiatan pengabdian ini di antaranya :

1) Metode Pendekatan

Metode pendekatan yang digunakan untuk mendukung realisasi kegiatan pengabdian ini di antaranya dengan pendekatan dengan Dukuh Karang Tengah, Desa Nogotirto, Kecamatan Gamping untuk memberikan informasi dan perizinan kepada pengusul untuk melakukan pengabdian kepada masyarakat. Setelah mendapat izin, pengabdi melakukan observasi kondisi lapangan dan lingkungan untuk mengetahui situasi riil lokasi dan memetakan daerah sasaran bidang terkait pengabdian masyarakat.

2) Metode Pelaksanaan

Pengabdian ini dilakukan dengan penyuluhan dan demonstrasi langsung kepada 
673 Pendampingan Masyarakat dalam Penguatan Imunitas Tubuh dengan Gizi Seimbang dan Suplemen di Era Adaptasi Kebiasaan Baru - Rosmauli Jerimia Fitriani, Margala Juang Bertorio, Rahmat A. Hi Wahid, Suharman

DOI: https://doi.org/10.31004/abdidas.v2i3.333

peserta yang hadir. Pertemuan pertama menggunakan metode ceramah dan demonstrasi secara langsung. Setelah acara selesai, dibentuk grup WhatsApp yang digunakan sebagai bahan diskusi oleh peserta yang hadir. Metode ceramah untuk menjelaskan tentang gizi seimbang dan suplemen kesehatan, membedakan suplemen kesehatan dan obat sebagai terapeutik dan pengetahuan masyarakat tentang Perilaku Hidup Bersih dan Sehat (PHBS). Metode demonstrasi untuk mempraktikkan PHBS yaitu 3M (Memakai masker, Mencuci tangan, Menjaga jarak dan Menghindari kerumunan) di era adaptasi kebiasaan baru.

3) Evaluasi Kegiatan

Setelah kegiatan berakhir diadakan diskusi kepada pasa peserta yang hadir mengenai materi yang sudah disampaikan oleh pengabdi.

\section{HASIL DAN PEMBAHASAN}

Kegiatan pengabdian ini dilakukan dalam rangka menjalankan Tri Dharma Perguruan Tinggi sebagai dosen, yaitu melakukan pengajaran, penelitian dan pengabdian kepada masyarakat.

Pengabdian ini dibuka oleh Dukuh Karang Tengah, yang menyampaikan tujuan dari adanya acara pengabdian ini. Dukuh Karang Tengah menyambut dengan baik acara yang bisa meningkatkan pengetahuan dan kesadaran masyarakat di era adaptasi kebiasaan baru ini.

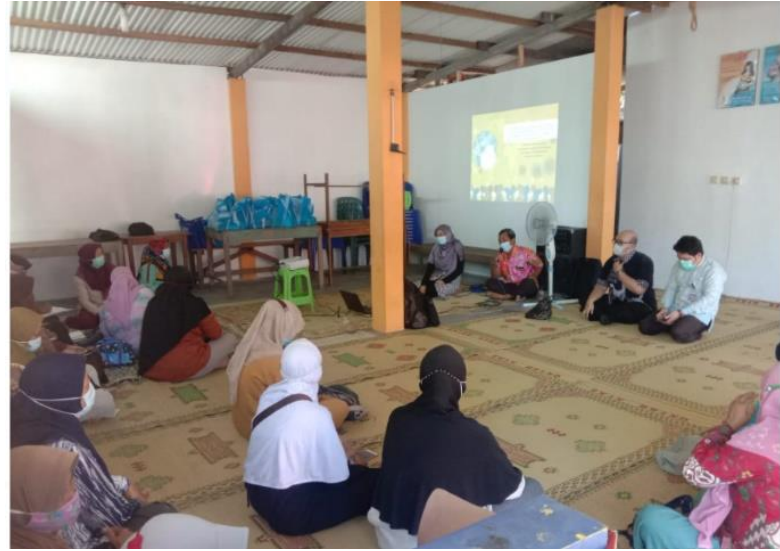

Gambar 1. Pembukaan Acara

Setelah acara dibuka, kemudian dilanjutkan dengan penyampaian materi yang pertama mengenai gizi seimbang yang dihadiri oleh kader kader kesehatan. Materi disampaikan dan ditampilkan di depan, yang dapat dilihat oleh seluruh peserta. Peserta mendapat informasi terbaru mengenai gizi seimbang dan pengolahan masakan. Peserta tertarik dengan warna warni buah dan sayur yang mempunyai kandungan gizi dan manfaatnya masing - masing. Dari acara ini peserta mendapat info mengenai metode pemasakan yang dianjurkan untuk mencegah kontaminasi bahan makanan. Setelah materi gizi seimbang, dilanjutkan dengan materi suplemen kesehatan. Materi suplemen kesehatan menjelaskan mengenai tujuan penggunaan suplemen kesehatan dan perbedaannya dengan obat - obatan. Setelah pemaparan materi, peserta melakukan tanya jawab dengan pemateri. Peserta sangat antusias untuk mendapatkan informasi dan konfirmasi mengenai isu - isu kesehatan selama pandemik Covid-19 ini. 
674 Pendampingan Masyarakat dalam Penguatan Imunitas Tubuh dengan Gizi Seimbang dan Suplemen di Era Adaptasi Kebiasaan Baru - Rosmauli Jerimia Fitriani, Margala Juang Bertorio, Rahmat A. Hi Wahid, Suharman

DOI: https://doi.org/10.31004/abdidas.v2i3.333

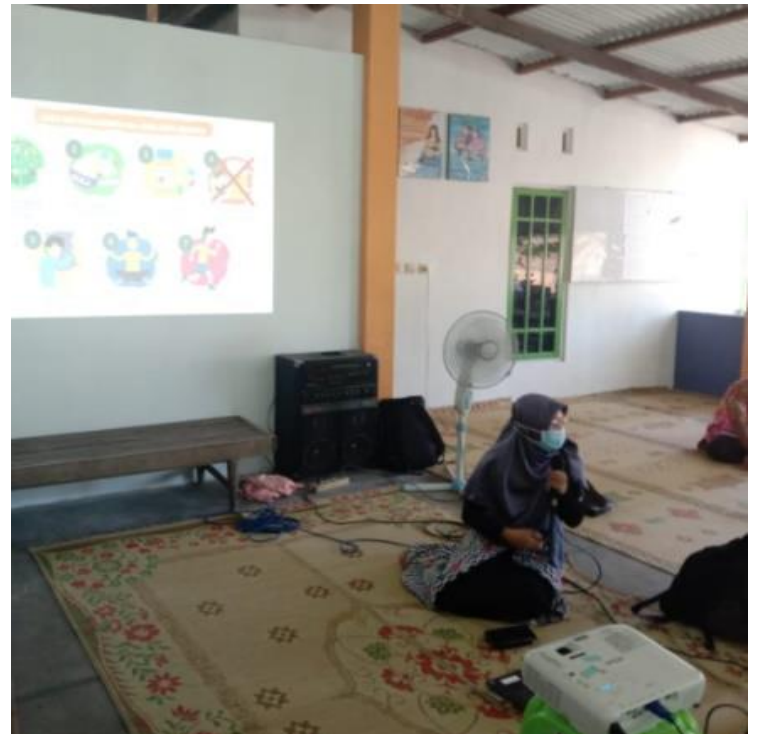

Gambar 2. Penyampaian Materi

Setelah materi dan tanya jawab selesai, diadakan pembagian hadiah untuk empat orang peserta yang beruntung, kemudian acara ditutup dengan foto bersama peserta dan pengabdi.

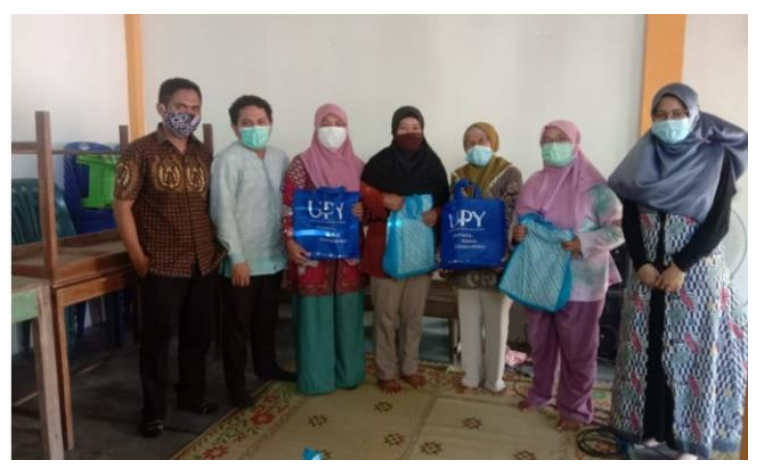

Gambar 3. Pembagian Hadiah

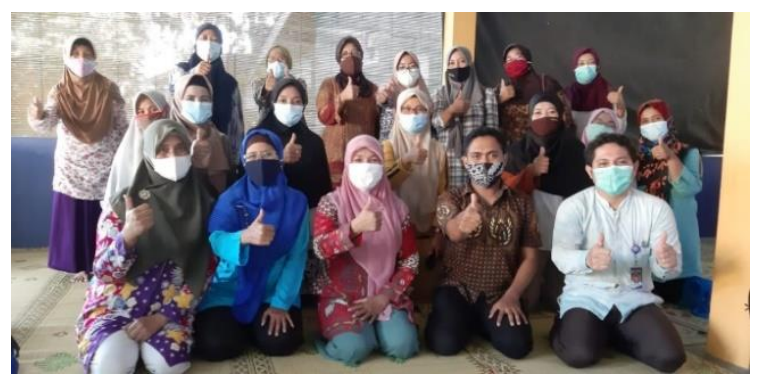

Gambar 4. Foto Peserta dan Pengabdi
Pengabdian ini berhasil meningkatkan pengetahuan masyarakat tentang gizi seimbang dan suplemen kesehatan, menumbuhkan pengetahuan masyarakat dalam membedakan suplemen kesehatan dan obat sebagai terapeutik serta menumbuhkan pengetahuan masyarakat tentang PHBS. Peserta mendapatkan ilmu baru mengenai gizi seimbang dan suplemen di era adaptasi kebiasaan baru. Dengan penjelasan dan contoh yang sudah diberikan oleh pengabdi, peserta dapat menerapkan hal tersebut pada keluarga dan masyarakat.

\section{SIMPULAN}

Kegiatan pendampingan masyarakat dalam penguatan imunitas tubuh dengan gizi seimbang dan suplemen kesehatan di era adaptasi kebiasaan baru terlaksana dengan baik. Peserta mendapat pengetahuan dan keterampilan baru mengenai gizi seimbang, pengolahan makanan dan suplementasi kesehatan.

\section{UCAPAN TERIMA KASIH}

Terima kasih kepada LPPM UPY karena Kegiatan Pegabdian Kepada Masyarakat ini dibiayai oleh dana bantuan Universitas PGRI Yogyakarta melalui anggaran LPPM tahun 2020/2021 dan kepada Dukuh Karang Tengah beserta para Kader di wilayah Padukuhan Karang Tengah.

\section{DAFTAR PUSTAKA}

Balanzá-Martínez, V., Atienza-Carbonell, B., Kapczinski, F., \& De Boni, R. B. (2020). Lifestyle behaviours during the COVID-19 - 
675 Pendampingan Masyarakat dalam Penguatan Imunitas Tubuh dengan Gizi Seimbang dan Suplemen di Era Adaptasi Kebiasaan Baru - Rosmauli Jerimia Fitriani, Margala Juang Bertorio, Rahmat A. Hi Wahid, Suharman

DOI: https://doi.org/10.31004/abdidas.v2i3.333

time to connect. Acta Psychiatrica

Scandinavica, 141(5), 399-400.

https://doi.org/10.1111/acps.13177

Chowdhury, M. A., Hossain, N., Kashem, M. A., Shahid, M. A., \& Alam, A. (2020). Immune response in COVID-19: A review. Journal of Infection and Public Health, 13(11), 16191629.

https://doi.org/10.1016/j.jiph.2020.07.001

Jenderal, D., \& Masyarakat, K. (2020). KEMITRAAN DALAM PENCEGAHAN COVID-19.

Kemenkes. (2020). Final-Panduan-Gizi-SeimbangPada-Masa-Covid-19-1.Pdf. Panduan Gizi Seimbang Pada Masa Pandemi COVID-19.

Kemenkes RI. (2020). Pedoman Pencegahan dan Pengendalian Coronavirus Disease (COVID19). Germas.

Park, K. H., Kim, A. R., Yang, M. A., Lim, S. J., \& Park, J. H. (2021). Impact of the COVID19 pandemic on the lifestyle, mental health, and quality of life of adults in South Korea. PLoS ONE, 16(2 February), 1-13. https://doi.org/10.1371/journal.pone.0247970

Selviana. (2020). Adaptasi Kebiasaan Baru. 06 Maret 2020.

Susilo, A., Rumende, C. M., Pitoyo, C. W., Santoso, W. D., Yulianti, M., Herikurniawan, H., ... Yunihastuti, E. (2020). Coronavirus Disease 2019: Tinjauan Literatur Terkini. Jurnal Penyakit Dalam Indonesia, 7(1), 45. https://doi.org/10.7454/jpdi.v7i1.415 